\title{
Management and Treatment of Hepatitis C: Are There Still Unsolved Problems and Unique Populations?
}

\author{
Virginia Solitano ${ }^{1,2}\left(\right.$, Maria Corina Plaz Torres ${ }^{2,3}$, Nicola Pugliese ${ }^{1,2}$ and Alessio Aghemo ${ }^{1,2, *}$ \\ 1 Department of Biomedical Sciences, Humanitas University, Pieve Emanuele, 20082 Milan, Italy; \\ virginia.solitano@humanitas.it (V.S.); nicola.pugliese@humanitas.it (N.P.) \\ 2 Division of Internal Medicine and Hepatology, Humanitas Research Hospital IRCCS, Rozzano, \\ 20089 Milan, Italy; maria.plaztorres@humanitas.it \\ 3 Gastroenterology Unit, Department of Internal Medicine, University of Genoa, IRCCS-Ospedale Policlinico \\ San Martino, 16132 Genoa, Italy \\ * Correspondence: alessio.aghemo@hunimed.eu; Tel.: +39-028-224-7006
}

Citation: Solitano, V.; Plaz Torres, M.C.; Pugliese, N.; Aghemo, A. Management and Treatment of Hepatitis C: Are There Still Unsolved Problems and Unique

Populations? Viruses 2021, 13, 1048. https://doi.org/10.3390/v13061048

Academic Editors: Pietro Andreone and Stefano Brillanti

Received: 7 April 2021

Accepted: 28 May 2021

Published: 1 June 2021

Publisher's Note: MDPI stays neutral with regard to jurisdictional claims in published maps and institutional affiliations.

Copyright: (c) 2021 by the authors. Licensee MDPI, Basel, Switzerland. This article is an open access article distributed under the terms and conditions of the Creative Commons Attribution (CC BY) license (https:// creativecommons.org/licenses/by/ $4.0 /)$.
Abstract: Direct-acting antivirals (DAA) have revolutionized the treatment of patients with chronic hepatitis $\mathrm{C}$ virus (HCV) infection, possibly leading to HCV elimination by 2030 as endorsed by the World Health Organization (WHO). However, some patients belonging to the so-called unique or special populations are referred to as difficult-to-treat due to unreached sustained virological response, potential drug side effects or interactions or co-morbidities. Several years after the DAA introduction and on the basis of excellent findings in terms of efficacy and safety, some doubts arise around the exact meaning of the special population designation and whether this group of patients actually exists. The aim of this review is to discuss and analyze current evidence on the management and treatment of the so-called "unique populations". We placed particular emphasis on patients with decompensated cirrhosis, chronic kidney disease (CKD), coinfections, rare genotypes, and previous treatment failure, in order to provide physicians with an updated overview of the actual problems and needs in the current scenario.

Keywords: hepatitis C; unique populations; special populations; decompensated cirrhosis; chronic kidney disease; end stage renal disease; $\mathrm{HIV} / \mathrm{HBV}$ coinfection; rare genotypes; treatment failure

\section{Introduction}

Direct-acting antivirals (DAA), including RNA-dependent polymerase inhibitors (antiNS5B), protease inhibitors (PI, anti-NS3/4A) and anti-NS5A inhibitors, have radically changed the landscape of patients with chronic hepatitis C virus (HCV) infection [1]. The availability of DAA together with the improvement of worldwide access to treatment could potentially lead to HCV elimination by 2030 as endorsed by the World Health Organization (WHO) [2]. However, some patients have historically been part of the so-called unique or special populations [3]. This term generally refers to those who are difficult-to-treat due to unreached sustained virological response (SVR), potential treatment side effects or drug interactions or co-morbidities [4].

In this context, the presence of liver decompensation and severe renal impairment may limit treatment options [5]. Moreover, due to the risk of re-activation of hepatitis $B$ virus (HBV) in patients with dual infections and to the risk of drug interactions in human immunodeficiency virus (HIV) co-infected individuals, careful consideration before therapy initiation is needed [6,7]. Notably, less treatment-susceptible genotypes (e.g., 11, 4r, $3 \mathrm{~b}, 3 \mathrm{~g}, 6 \mathrm{u}, 6 \mathrm{v}$ ) is an emerging challenge and DAA treatment failure involves a significant proportion of patients (approximately $1-3 \%$ of all HCV patients) [8,9].

Several years after the DAA introduction, some doubts arise regarding the exact meaning of the special population designation and who should belong to this group [10]. 
In this review, we aim to collect current evidence on the management and treatment of special populations that have been traditionally considered difficult-to-treat due to pharmacological, virological, and co-morbidity reasons. In particular, the review focuses on patients with decompensated cirrhosis, chronic kidney disease (CKD), coinfections, rare genotypes and previous treatment failure, in order to provide with an updated overview of the unsolved problems and needs in the 2021 scenario.

\section{Patients with Decompensated Cirrhosis}

Patients with decompensated (Child-Pugh B or C) HCV-related cirrhosis have always been considered a difficult-to-treat cohort for which treatment options were limited and only liver transplantation could represent a definitive cure [11]. Due to the substantially elevated drug exposure and liver injury associated with NS3/4A PI, PI-containing regimens are not allowed in $\mathrm{HCV}$ patients with current or past decompensated cirrhosis [12]. Occurrence of liver failure or death due to the use of NS3/4A PI has been reported, and in 2019 the Food and Drug Administration (FDA) raised a safety warning about PI-containing regimens in these patients [13]. Figure 1 summarizes metabolism and distribution of the several available DAA.

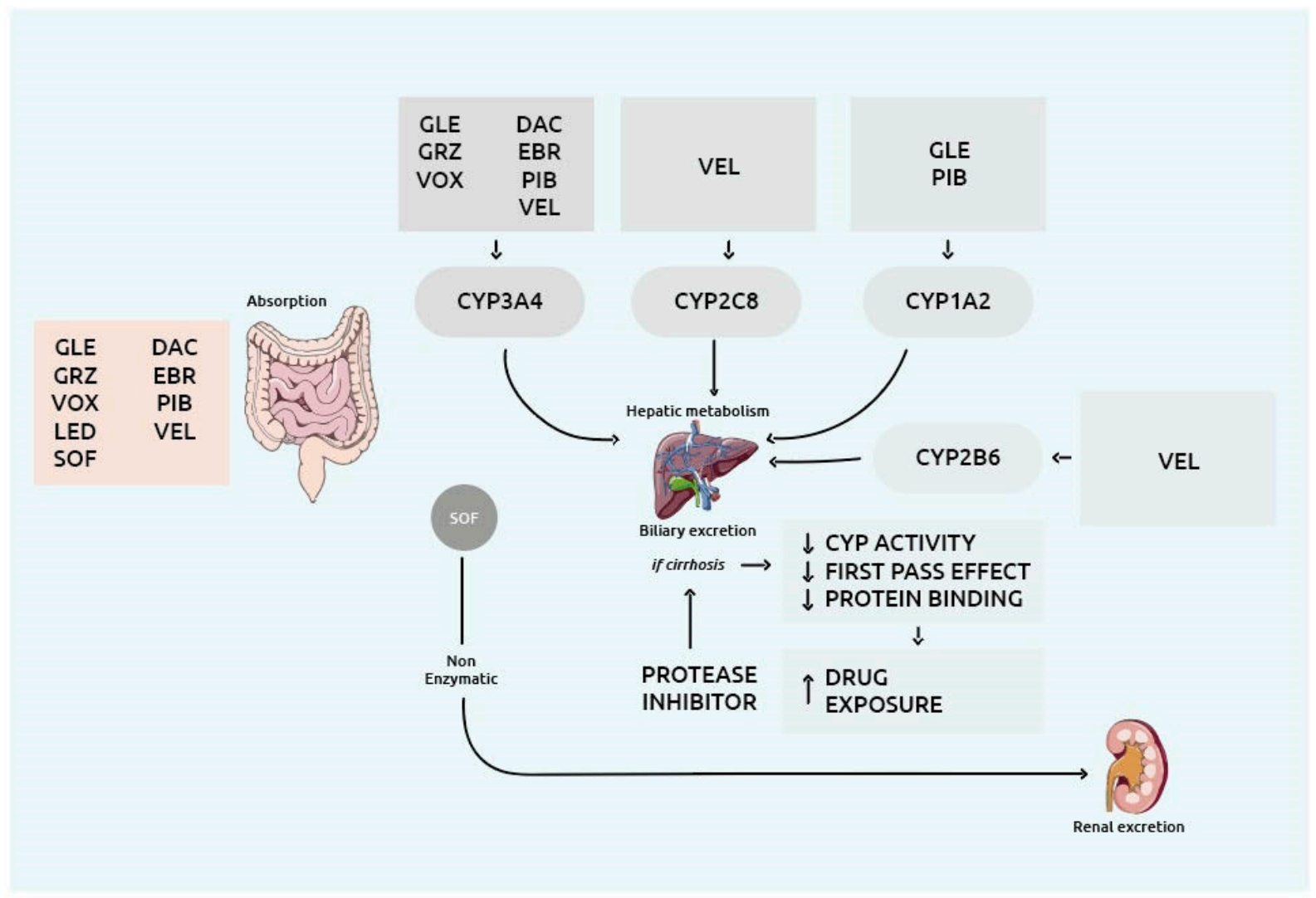

Figure 1. Overview of the drug metabolism enzymes and drug transporters involved in the metabolism and distribution of the several DAA. Abbreviations: CYP: cytochrome P450; DAC: daclatasvir; EBR: elbasvir; GLE: glecaprevir; GRZ: grazoprevir; LED: ledipasvir; PIB: pibrentasvir; SOF: sofosbuvir; VEL: velpatasvir; VOX: voxilaprevir.

Among non-PI based DAA, the treatment of choice for patients with current decompensated cirrhosis or with compensated (Child-Pugh A) cirrhosis with prior episodes of decompensation consists of the fixed-dose combination of sofosbuvir (SOF) and velpatasvir (VEL) regimens. The paradigmatic ASTRAL-4 phase III randomized trial evaluated the efficacy and safety of a fixed-dose combination of SOF/VEL with or without ribavirin (RBV) for 12 weeks or SOF/VEL for 24 weeks in 267 treatment-naïve and treatment-experienced decompensated patients (Child-Pugh class B) [14]. Notably, overall rates of SVR at 12 weeks 
after the end of treatment (SVR12) were 83\% in patients treated without RBV (including all genotypes), compared to $94 \%$ among those receiving SOF/VEL plus RBV for 12 weeks [14]. However, considering only patients with HCV genotype $3(15 \%)$, the SVR was $85 \%$ in those receiving SOF/VEL plus ribavirin, dropping to $50 \%$ in those receiving the same DAA combination without ribavirin [14].

Data from the real-world multicenter TARGET study, including 170 decompensated patients showed that treatment with ledipasvir (LDV)/SOF with or without RBV led to optimal response rates (SVR12 88\%, regardless of HCV genotype) [15]. Consistently, other two real-world studies from the United Kingdom (UK) including large cohorts of patients with decompensated cirrhosis showed that anti-HCV DAA treatment is beneficial even in this group of patients $[16,17]$. A more recent Japanese real-world study reported an SVR12 rate of $90 \%$ in a cohort of 82 patients with decompensated cirrhosis and significant improvements in Child-Pugh score after treatment. For instance, $50 \%$ of patients with class $\mathrm{B}$ at baseline reached class A Child-Pugh score whereas around one third and one tenth of baseline class C Child-Pugh patients were class B and A, respectively, at the end of treatment [18].

Considerably, the cost-effectiveness of SOF/VEL plus RBV in advanced decompensated patients has been recently highlighted by a state-transition model that compared this DAA combination therapy with best supportive care [19]. SOF/VEL decreased the range of liver-related deaths and progression to Child Pugh C cirrhosis by $20.4 \%$ and $21.9 \%$, respectively, with an incremental cost-effectiveness ratio of $\$ 39,169$ per quality-adjusted life years [19].

Despite clinical trials and real-world studies showing excellent rates of SVR and costeffectiveness with SOF-based regimens with a lower decompensated cirrhosis risk [20], predictors of response in this peculiar group are scarce. Interestingly, Debnath and coworkers (2020) found that albumin, alanine transaminase (ALT), bilirubin, and estimated glomerular filtration rates (eGFR) were independently associated with treatment response (odds ratio $[\mathrm{OR}]=4.84,1.02,0.41,1.03$ for the above-mentioned variables, respectively; $p<0.05$ ) [21]. In addition, patients with a model for end-stage liver disease (MELD) score $>15$ and a Child Pugh $C$ score did not achieve a persistent compensated state 36 weeks after treatment (primary end-point) and authors concluded that early liver transplantation should be mandatory in this case [21].

Not to be overlooked, a recent long-term (median follow-up of 4 years) evaluation of patients with advanced or decompensated cirrhosis (MELD $\geq 10$ ) showed marginal (0.3 point) and not-meaningful improvement in MELD score after an NS5A-containing DAA treatment (reduction of MELD by 3 or more points and MELD score of $<10$ in $25 \%$ and 29\%, respectively), regardless of SVR [22]. Therefore, the impact of SVR response on liver function should not be optimistically overestimated in this group of patients that still require close monitoring and special attention [22].

\section{Patients with Renal Impairment, Including End-Stage Renal Disease on Hemodialysis}

The reciprocal relationship between HCV infection and CKD is well established [23]. Robust data demonstrated that chronic HCV infection can cause per se renal impairment which may be secondary to HCV-related mixed cryoglobulinemia or, in the absence of cryoglobulinemia, to direct viral invasion of the renal parenchyma, and to nephrotoxicity of drugs used for its treatment $[23,24]$. These mechanisms often interact in the pathogenesis of several acute and chronic clinical renal syndromes $[23,25]$. The histopathological lesions vary from segmental glomerulosclerosis to membrane-proliferative glomerulonephritis and interstitial nephritis [26]. On the other hand, especially in countries where HCV is highly prevalent (such as Russia, Egypt, Syria, Georgia, and others in southern and eastern Asia), $\mathrm{HCV}$ is frequently detected in patients with a pre-existent renal impairment due to other clinical conditions [27].

Moreover, end-stage renal disease requiring dialysis may increase the risk of HCVinfection, especially in dialysis units where hygienic measures are poor $[23,24]$. HCV- 
infection, in turn, raises the risk of mortality in dialysis population and that of hepatic function deterioration in patients receiving kidney transplantation [23,24].

In this scenario, anti-viral treatment with DAA may play a pivotal role in the amelioration and even prevention of renal impairment [25]. For instance, El-Serag et al. (2019) showed that successful HCV treatment with DAA actually prevented the onset of glomerulonephritis in a population of 45,260 male subjects from the US Department of Veterans Affairs Corporate Data Warehouse [28]. In the treated cohort the risk of CKD was significantly reduced as compared with the untreated group (adjusted hazard ratio [aHR] $=0.61$; $95 \%$ confidence interval [CI], 0.41-0.90). Additionally, remissions from glomerular disease have been reported in patients achieving SVR after treatment with DAA, although data on the improvement of renal lesions after successful DAA treatment are scarce [29]. However, organ recovery may be delayed after an SVR in patients with cryoglobulinemia [30].

Whilst no safety concerns are present for CKD patients undergoing DAA treatment with either the combination of glecaprevir (GLE)/pibrentasvir (PIB) or elbasvir/ grazoprevir [25,31] independently from the disease stage and including those on hemodialysis, renal safety of the treatment combinations based on SOF has been questioned [32]. Indeed, data regarding the safety of SOF in renal impairment are controversial [33-36].

In 2016 Saxena et al. reported a higher frequency of renal function worsening and serious adverse events (AEs) (all $p<0.05$ ) in patients with a baseline eGFR $<45 \mathrm{~mL} / \mathrm{min}$ treated with SOF-containing regimens [36]. However, a significant number of studies aimed at verifying the safety of SOF-based regimens in patients with an established diagnosis of CKD, showed no significant changes in renal function [33] nor AEs associated with renal function, even in patients receiving dialysis $[34,35]$. The safety of the SOF/VEL combination has been recently evaluated in a 12-week non-controlled study including 59 patients with end-stage renal disease requiring hemodialysis [34]. The exposure of SOF metabolite GS-331007 was increased 20-fold, exceeding levels where adverse reactions have been observed in preclinical trials. This notwithstanding, the rate of AEs and deaths was not higher than expected in patients with end stage renal disease [34].

Available data consistently showed optimal rates of SVR with all the approved pangenotypic treatments in patients with severe CKD and on hemodialysis, including full-dose SOF-based regimens [33-35]. The magnitude of recent studies confirming the safety profile of SOF is of fundamental importance in contexts where resources are limited and in cases of decompensated cirrhosis where SOF-based regimens with or without RBV represent the only option [33-35,37]. As a result, patients with HCV infection and concomitant CKD do not appear as a difficult-to-treat population to date and IFN-free pan-genotypic treatments can be recommended in all patients with kidney disease, without dose-adjustments $[25,38]$.

\section{Patients with HBV/HIV Coinfections}

\subsection{Patients with Concomitant HBV Infection}

In patients with HCV and HBV coinfection, DAA treatment should be prescribed similarly to HCV-mono-infected patients. However, HBV re-activation in HBsAg-positive patients may occur during and after DAA treatment in a considerable proportion of patients [39-41]. The underlying mechanisms of HBV re-activation during/after pan-oral DAA treatment may rely on the HCV-related suppression of HBV replication but the exact pathway of such suppression is poorly understood [39].

Cases of HBV re-activation (detected by the evidence of quantifiable HBV-DNA levels or an increase $>1 \log 10 \mathrm{IU} / \mathrm{mL}$ from baseline) and ALT elevations $>2$ times upper normal level have been reported in up two thirds of HBsAg positive patients treated with DAA $[40,42,43]$. In most patients the increase of HBV DNA levels was not associated with signs or symptoms of hepatitis and ALT elevations were mostly mild [40,43-45]. Still, approximately $4 \%$ of patients with HBV re-activation after DAA treatment need to start antiviral treatment $[39,40]$ and importantly, HBV re-activation in cirrhotic patients may lead to liver failure and death despite immediate nucleoside or nucleotide analogue (NUC) therapy [46]. 
As such, taking into account that no strong predictive factors for HBV re-activation have been demonstrated, the most recent European Association for the Study of the Liver (EASL) guidelines recommend to start concurrent prophylactic HBV NUC therapy in all HBsAg-positive patients commencing DAA-based treatment [25]. Differently from EASL recommendations, the American Association for the Study of Liver Disease (AASLD) states that monitoring HBV DNA and ALT every $4-8$ weeks for 3 months post-DAA is appropriate in co-infected patients positive for HBsAg [47]. The lack of unanimous agreement regarding the management of these patients suggests that $\mathrm{HCV} / \mathrm{HBV}$ co-infected are still a special population and future studies are expected to clarify the best therapeutic approach for this cohort [6].

\subsection{Patients with HIV Co-Infection}

$\mathrm{HCV}$ patients co-infected with HIV carry a higher risk of fibrosis progression leading to a faster occurrence of cirrhosis and related complications [48]. HIV infection, indeed, causes direct and indirect liver injury due to interactions with hepatic stellate cells and the immune system which accelerate extracellular matrix production and pro-fibrotic pathways [49]. Moreover, HCV/HIV co-infected patients show higher rates of decompensation and HCV-viral loads, with an increased risk of drug interactions and altered absorption of antivirals [50,51].

Since the advent of DAA, several trials have been conducted addressing the outcomes for the unique population of $\mathrm{HCV} / \mathrm{HIV}$ co-infected patients. All studies reported optimal efficacy and safety results. In particular SVR rates for patients with dual HCV/HIV infection treated with pan-genotypic regimens were comparable to those with HCV monoinfection [52-63].

For instance, in the ASTRAL study, including 106 patients treated with SOF/VEL, SVR rate was 95\% (95\% CI: 89-99\%). In the EXPEDITION-2 and ENDURANCE-1 studies, which investigated the safety and efficacy of GLE/PIB in HIV / HCV co-infected patients SVR rates ranged from $95 \%$ for HCV-3 to $99 \%$ for HCV-1 infected patients, respectively. These SVR rates are comparable to those of the HCV mono-infected population [54,55].

In summary, DAA pan-genotypic treatments can be safely recommended in $\mathrm{HIV} / \mathrm{HCV}$ co-infected subjects [64]. Indeed, the most recent European AIDS Clinical Society (EACS) guidelines recommended timely HCV therapy in HIV-positive patients with low CD4-count $(<200 / \mu \mathrm{L})$, with persistent HIV-viremia and HBV-coinfection [65]. No drug interactions nor lower SVR rates are expected in HIV-infected patients treated with DAA based on the combination of GLE/PIB or SOF/VEL or SOF/VEL/voxilaprevir (VOX) $[65,66]$. Attention is required only when LDV-based regimen is prescribed in patients treated with tenofovir and ritonavir-boosted HIV protease-inhibitors [64]. In addition, LDV/SOF treatment should not be prescribed in patients treated with cobicistat, elvitegravir and tipranavir [64] The latest AASLD guidelines suggested the collaboration between hepatologists and infectious disease specialists when drug switches are needed [64]. However, given the paucity of drug-drug interactions and the safety of DAA, such cases are rare and most patients continue antiretroviral treatment during HCV treatment safely [64].

In conclusion, though antiretroviral HIV drugs should be taken into account before starting DAA treatment and physicians should always consider possible barriers impacting SVR such as drug injection, alcohol abuse, psychiatric disorders, and incarceration, it seems inappropriate to still regard HCV/HIV patients as special populations [67].

\section{Patients with less Treatment-Susceptible HCV-Subtypes}

While the WHO set the objective to eliminate hepatitis C by 2030, only few wealthy states seem able to reach the goal, among a vast majority of low-middle income countries $[68,69]$. As one of the causes for the unlikely HCV elimination in the planned timeframe, it should be mentioned that DAA combinations may not be as pan-genotypic as claimed [70]. According to the EASL guidelines, pan-genotypic antiviral regimens, including GLE/PIB and SOF/VEL, can be administered without the need to identify HCV 
genotype and subtype. However, based on the most recent literature, we think that genotype and subtype identification before starting the treatment appears useful in specific settings (such as in patients from geographical areas where less treatment-susceptible subtypes are known to be prevalent) in order to optimize treatment regimens [5].

Indeed, some subtypes of genotypes 1 to 8 that are uncommon in Western countries have been shown to be prevalent in some regions of Asia and Africa and among migrants from these areas (defined as genotype 1 non- $1 a / 1 b$, genotype 2 non- $2 a / 2 b$, genotype 3 non$3 a$, genotype 4 non-4a/4d, and subtypes of genotypes 5 to 8 ) [71-73]. Data on treatment outcomes in these uncommon genotypes and subtypes are limited.

In a large-scale single arm trial performed in Rwanda, Gupta et al. (2019) showed that genotype $4 r$, found in $16 \%$ of patients, was associated with high rates of treatment failure with LDV/SOF in combination (SVR12 $=56 \%$ vs. 93\%, respectively), despite appropriate compliance [74]. This could be associated to the existence of an amino acid motif of the NS5A protein that confers high-level resistance to DAA in vitro [75]. In accordance with these findings, the French National Reference Centre recently described that subtype $4 \mathrm{r}$ is associated with lower SVR rates [76]. Among DAA-treated patients who experienced a virological failure in France between 2015 and 2018, 22.5\% were infected with genotype 4, more specifically $5 \%$ with subtype $4 \mathrm{r}$, which is rare among the French population. Treatment failure was related to multiple NS5A resistance-associated substitutions (RASs) which were actually present in all subtype $4 \mathrm{r}$ patients at baseline [76].

Consistently with the previous studies, Childs et al. (2019) reported suboptimal rates of SVR in a London cohort of African patients infected with uncommon HCV genotype subtypes [71]. Over an eight-year period, the authors identified 91 African-born patients, $35(38.5 \%)$ of those infected with unusual HCV genotype 1 subtypes (including $1 \mathrm{e}, 1 \mathrm{~g}, 1 \mathrm{~h}$, 11 or unassigned genotype 1 ) and $12(13.1 \%)$ with unusual genotype 4 subtypes (including $4 \mathrm{c}, 4 \mathrm{e}, 4 \mathrm{f}, 4 \mathrm{k}$ and $4 \mathrm{r}$ ). After DAA treatment (SOF/LDV, paritaprevir/ritonavir/ombitasvir dasabuvir, or elbasvir/grazoprevir), SVR was observed only in $75 \%$ African patients infected with uncommon genotype 1 subtypes $(1 \mathrm{p}, 1 \mathrm{l})$ compared to $100 \%$ in all other genotypes and subtypes. In this context, as well as in the above-mentioned studies, failures of NS5A inhibitor-containing regimens, were explained by the frequency of NS5A RASs that could be considered as a natural polymorphism in African subtypes [71].

On the contrary, reassuring data come from a study by Zeuzem et al. (2017)., including 25 participants with uncommon genotype 1 subtypes, such as $1 \mathrm{c} / \mathrm{e} / \mathrm{g} / \mathrm{h} / \mathrm{l}$. All subjects achieved SVR with an NS5A inhibitor-based regimen (LDV/SOF, SOF/VEL, or SOF/VEL/VOX) [77]. However, it should be mentioned that most patients received either LDV/SOF for 24 weeks or SOF/VEL (with or without VOX). Therefore, it is plausible that such a successful virological response, despite high rates of RASs, was influenced by either the use of the most potent antiviral regimen available or the prolonged treatment [77].

In view of the above, people from areas with a high prevalence of less treatmentsusceptible HCV subtypes, may benefit from determination of genotype and subtype or deep sequencing of the NS5B so as to avoid treatment failure. Moreover, clinical trials and real-world studies are necessary to define the efficacy of DAA regimens against such unusual subtypes.

Therefore, it can be affirmed that patients with unusual genotypes (such as $11,4 \mathrm{r}$, $3 \mathrm{~b}, 3 \mathrm{~g}, 6 \mathrm{u}$ and $6 \mathrm{v}$ ) represent a unique population and that assessing the efficacy of DAA treatment in these constitutes a priority challenge in the near future in order to obtain $\mathrm{HCV}$ elimination worldwide. In our opinion, due to the scarcity of data, patients infected with uncommon subtypes should be treated with 12 weeks of the fixed combination of SOF/VEL/VOX [5]. 


\section{Patients with Previous DAA Failure}

While failure to DAA is rare, SVR rates have reached $95-99 \%$ across all HCV genotypes, the cohort of $\mathrm{HCV}$ patients requiring retreatment with DAA-salvage treatments is numerically large $[78,79]$.

Factors associated with DAA failure include decompensated cirrhosis, lack of compliance, presence of hepatocellular carcinoma, and uncommon HCV genotype subtypes [80,81]. DAA treatment failures also occur in instances characterized by high prevalence of RASs in the region targeted by the administered drugs. Of note, NS5A RASs prior to therapy had a negative impact on virological response, leading to lower SVR rates ( $76 \%$ vs. $97 \%$ among treatment-experienced genotype 1a patients) [82]. On the contrary, NS5B protein's RASs limiting the efficacy of drugs such as SOF are harder to detect, as these variants typically replicate very poorly [83].

Many guidelines recommend RASs testing prior to re-treatment in patients who do not achieve SVR, but the benefit and cost-effectiveness of this approach has not been consistently documented [5,84].

As a matter of principle, re-treatment should be based on SOF-based regimens, as a drug with the highest genetic barrier to resistance [9]. In addition, regimens containing the same class of DAA that caused the failure should be avoided [9]. Finally, if resistance testing is performed, it is worth considering probabilities of response according to the resistance profile observed [9].

According to the most recent EASL guidelines, the first line treatment for DAA-failure is a 12 weeks SOF/VEL/VOX regimen. The evidence for such recommendation was initially derived from the POLARIS 1 and 4 trials [85]. In the POLARIS-1 study, patients (genotype 1-6) who failed an NS5A inhibitor-containing regimen achieved a 96\% SVR12 (253/263) following a 12-week course of SOF/VEL/VOX. The POLARIS 4 trial confirmed the superiority of this triple therapy versus a double drug regimen (SOF/VEL) in genotype 1-4-infected patients with prior NS5B-inhibitor and/or NS3-PI (but not NS5A-inhibitor) treatment failure [85]. Subsequently, several real-world studies confirmed the high efficacy and safety of the triple combination regardless of patient gender, HCV genotype, and baseline HCV RNA $[81,86,87]$. The only pre-treatment parameter associated with a lower SVR rate in SOF/VEL/VOX treated patients was the presence of advanced liver disease (F4) [81].

A valid alternative to SOF/VEL/VOX for patients with predictors of poor response, such as advanced cirrhosis, complex RASs patterns, or failure to multiple courses of treatment, is a 12-week course of SOF+GLE/PIB [5]. In fact, a phase IIIb trial showed that 22 out of 23 patients who were retreated with the triple combination of SOF+GLE/PIB for 12 or 16 weeks after a GLE/PIB-regimen failure achieved SVR12 (96\%) [88].

A "very difficult-to-treat" population is represented by subjects with NS5A RASs who failed twice to achieve an SVR after a combination regimen including a PI and/or an NS5A inhibitor. The management of these patients has not been yet resolved. The EASL guidelines suggest the possibility of using the above-mentioned triple regimens (SOF/VEL/VOX and $\mathrm{SOF}+\mathrm{GLE} / \mathrm{PIB}$ ) with the addition of RBV [5]. However, this recommendation remains to be validated by prospective studies in the near future.

Patients with decompensated cirrhosis and prior DAA failure are another "very difficult-to-treat" population, as PI are contraindicated, and the only recommended regimen is SOF/VEL combination therapy plus RBV for 24 weeks. Nevertheless, given possible baseline NS5A RASs and poor tolerance to full course RBV, this combination is associated with suboptimal SVR rates, especially in HCV-3 patients (78\% [95\% CI: $52-94 \%$ ] in HCV-3 vs. 97\% [95\% CI: 86-100\%] and 93\% [95\% CI: 66-100\%] in HCV-1 and HCV-2, respectively) [89].

In summary, the available evidence highlights that patients with previous DAA failures with or without negative prognostic factors (e.g., decompensated cirrhosis) constitute a difficult-to-treat population and that further studies providing consistent data on the best therapeutical approach for these patients are necessary [9]. 


\section{Conclusions}

DAA have undoubtedly allowed all HCV-infected patients to be potentially cured of their disease. Moreover, in most patients belonging to groups historically considered difficult-to-treat (e.g., CKD, HCV/HIV co-infected) the SVR rates are optimal with very good safety and tolerability profiles (Table 1).

Table 1. Unique populations over time.

\begin{tabular}{|c|c|c|c|}
\hline Population & Past & Current State of the Art & Future Perspectives \\
\hline Decompensated cirrhosis & $\begin{array}{l}\text { Unique population due to } \\
\text { higher risk for } \\
\text { decompensation and side } \\
\text { effects during antiviral } \\
\text { therapy }\end{array}$ & $\begin{array}{l}\text { Special attention required due } \\
\text { to exposure to long-term } \\
\text { complications. } \\
\text { Negative prognostic factor } \\
\text { overall }\end{array}$ & $\begin{array}{l}\text { Not overestimate the impact } \\
\text { of SVR on liver function and } \\
\text { not overlook the possible } \\
\text { persisting need for LT }\end{array}$ \\
\hline
\end{tabular}

Unique population due to:

$\checkmark \quad$ increased prevalence of

\section{CKD in HCV}

$\checkmark \sqrt{ }$ high prevalence of HCV

Special attention not required.

hemodialysis

No need for caution about None

$\sqrt{ } \quad$ increased risk of

SOF-based regimens

all-cause mortality

\begin{tabular}{clll}
\hline HCV /HIV infection & $\begin{array}{l}\text { Historically considered } \\
\text { difficult- to-treat due to low } \\
\text { SVR rates }\end{array}$ & $\begin{array}{l}\text { No longer a unique } \\
\text { population. } \\
\text { Attention only to few } \\
\text { interactions between DAA } \\
\text { and anti-retroviral drugs }\end{array}$ & None \\
\hline HCV/HBV infection & $\begin{array}{l}\text { Historically considered at risk } \\
\text { of developing complications } \\
\text { (e.g., cirrhosis and HCC) } \\
\text { compared to those with } \\
\text { mono-infection. }\end{array}$ & $\begin{array}{l}\text { Relevant risk of HBV } \\
\text { re-activation in HBsAg } \\
\text { positive during and after DAA } \\
\text { therapy }\end{array}$ & $\begin{array}{l}\text { Agreement among } \\
\text { international societies } \\
\text { regarding the best therapeutic } \\
\text { approach }\end{array}$ \\
\hline Unusual subtypes & Unknown & $\begin{array}{l}\text { Emerging challenge due to the } \\
\text { paucity of data }\end{array}$ & $\begin{array}{l}\text { Future studies expected to } \\
\text { clarify the best DAA regimen }\end{array}$ \\
\hline Prior DAA failure & Unknown & $\begin{array}{l}\text { Emerging challenge due to } \\
\text { uncertainties regarding the } \\
\text { recommended therapeutic } \\
\text { approach }\end{array}$ & $\begin{array}{l}\text { Prospective studies expected } \\
\text { to validate international } \\
\text { societies' recommendations }\end{array}$
\end{tabular}

Abbreviations: CKD, chronic kidney disease; DAA, direct-acting antivirals; HBV, hepatitis B virus; HCC hepatocellular carcinoma; HCV, hepatitis C virus, HIV, human immunodeficiency virus; LT, liver transplantation; SOF, sofosbuvir.

Patients with CKD or needing hemodialysis do not require special attention, and the use of SOF-based regimens in these cases has been endorsed by the latest EASL guidelines. Moreover, subjects with $\mathrm{HCV} / \mathrm{HIV}$ co-infection are no longer to be considered a unique population and therefore attention should be paid only to the few interactions between DAA and antiretroviral HIV drugs.

However, unsolved problems persist even in the era of pan-genotypic DAA. Despite achieving SVR in most cases, patients with decompensated advanced liver disease remain exposed to long-term complications (such as hepatocellular carcinoma, ascites, hepatic encephalopathy, variceal bleeding) and HCV elimination might lead these subjects to be listed at a lower priority for liver transplantation [90]. As a result, we believe this group still requires close monitoring and special attention.

Furthermore, given the clinically relevant risk of reactivation of HBV after DAA cure, uncertainties about the best therapeutic approach for patients with dual HCV/HBV infec- 
tion are still present and the lack of agreement among international societies' guidelines makes the issue controversial.

In addition, the management of patients with unusual subtypes (e.g., 11, 4r, 3b, 3g, $6 \mathrm{u}$ and $6 \mathrm{v}$ ) and of those with prior DAA treatment failure is still a matter of concern. Furthermore, the co-existence of negative prognostic factors such as decompensated cirrhosis makes these subjects even more difficult-to-treat; hence, future studies are expected to clarify the best DAA regimen to administer to these cohorts.

Author Contributions: Conceptualization, V.S. and A.A.; writing-original draft preparation, V.S., M.C.P.T., N.P.; writing - review and editing, A.A. All authors have read and agreed to the published version of the manuscript.

Funding: This research received no external funding.

Institutional Review Board Statement: Not applicable.

Informed Consent Statement: Not applicable.

Data Availability Statement: Not applicable.

Conflicts of Interest: Alessio Aghemo has served as a speaker, a consultant and advisory board member for Gilead, MSD, Abbvie, Mylan, Intercept and Alfasigma and has received research funding from Gilead and Abbvie. The other authors declare no conflict of interest.

\section{References}

1. Laursen, T.L.; Sandahl, T.D.; Kazankov, K.; George, J.; Grønbæk, H. Liver-related effects of chronic hepatitis C antiviral treatment. World J. Gastroenterol. 2020, 26, 2931-2947. [CrossRef]

2. Heffernan, A.; Cooke, G.S.; Nayagam, S.; Thursz, M.; Hallett, T.B. Scaling up prevention and treatment towards the elimination of hepatitis C: A global mathematical model. Lancet 2019, 393, 1319-1329. [CrossRef]

3. Toussaint-Miller, K.A.; Andres, J. Treatment Considerations for Unique Patient Populations with HCV Genotype 1 Infection. Ann. Pharmacother. 2015, 49, 1015-1030. [CrossRef] [PubMed]

4. Gish, R.G.; Afdhal, N.H.; Dieterich, D.T.; Reddy, K.R. Management of hepatitis C virus in special populations: Patient and treatment considerations. Clin. Gastroenterol. Hepatol. 2005, 3, 311-318. [CrossRef]

5. Pawlotsky, J.M.; Negro, F.; Aghemo, A.; Berenguer, M.; Dalgard, O.; Dusheiko, G.; Marra, F.; Puoti, M.; Wedemeyer, H. EASL recommendations on treatment of hepatitis C: Final update of the series. J. Hepatol. 2020, 73, 1170-1218. [CrossRef] [PubMed]

6. Shih, Y.-F.; Liu, C.-J. Hepatitis C Virus and Hepatitis B Virus Co-Infection. Viruses 2020, 12, 741. [CrossRef]

7. Esposito, I.; Labarga, P.; Barreiro, P.; Fernandez-Montero, J.V.; de Mendoza, C.; Benítez-Gutiérrez, L.; Peña, J.M.; Soriano, V. Dual antiviral therapy for HIV and hepatitis C-Drug interactions and side effects. Expert Opin. Drug Saf. 2015, 14, 1421-1434. [CrossRef]

8. Di Biagio, A.; Taramasso, L.; Cenderello, G. Treatment of hepatitis C virus genotype 4 in the DAA era. Virol. J. 2018, 15, 180. [CrossRef]

9. Parigi, T.L.; Torres, M.C.P.; Aghemo, A. Upcoming direct acting antivirals for hepatitis C patients with a prior treatment failure. Clin. Mol. Hepatol. 2019, 25, 360-365. [CrossRef]

10. Krekulova, L.; Honzák, R.; Riley, L.W. Viral hepatitis C pandemic: Challenges and threats to its elimination. J. Viral Hepat. 2021, 28, 694-698. [CrossRef]

11. Dailey, F.; Ayoub, W.S. Hepatitis C Virus Therapy for Decompensated and Posttransplant Patients. J. Clin. Gastroenterol. 2017, 51, 215-222. [CrossRef] [PubMed]

12. Mak, L.-Y.; Seto, W.-K.; Lai, C.-L.; Yuen, M.-F. An update on the toxicological considerations for protease inhibitors used for hepatitis C infection. Expert Opin. Drug Metab. Toxicol. 2018, 14, 483-491. [CrossRef] [PubMed]

13. U.S. Food and Drug Administration. FDA Warns about Rare Occurrence of Serious Liver Injury with Use of Hepatitis C Medicines Mavyret, Zepatier, and Vosevi in Some Patients with Sdvanced Liver Disease; U.S. Food and Drug Administration: Washington, DC, USA, 2019.

14. Curry, M.P.; O’Leary, J.G.; Bzowej, N.; Muir, A.J.; Korenblat, K.M.; Fenkel, J.M.; Reddy, K.R.; Lawitz, E.; Flamm, S.L.; Schiano, T.; et al. Sofosbuvir and Velpatasvir for HCV in Patients with Decompensated Cirrhosis. N. Engl. J. Med. 2015, 373, 2618-2628. [CrossRef] [PubMed]

15. Terrault, N.A.; Zeuzem, S.; di Bisceglie, A.M.; Lim, J.K.; Pockros, P.J.; Frazier, L.M.; Kuo, A.; Lok, A.S.; Shiffman, M.L.; Ben-Ari, Z.; et al. Effectiveness of Ledipasvir-Sofosbuvir Combination in Patients with Hepatitis C Virus Infection and Factors Associated with Sustained Virologic Response. Gastroenterology 2016, 151, 1131-1140.e5. [CrossRef] [PubMed]

16. Foster, G.R.; Irving, W.L.; Cheung, M.C.M.; Walker, A.J.; Hudson, B.E.; Verma, S.; Mclauchlan, J.; Mutimer, D.J.; Brown, A.; Gelson, W.T.H.; et al. Impact of direct acting antiviral therapy in patients with chronic hepatitis $\mathrm{C}$ and decompensated cirrhosis. J. Hepatol. 2016, 64, 1224-1231. [CrossRef] [PubMed] 
17. Cheung, M.C.M.; Walker, A.J.; Hudson, B.E.; Verma, S.; McLauchlan, J.; Mutimer, D.J.; Brown, A.; Gelson, W.T.H.; MacDonald, D.C.; Agarwal, K.; et al. Outcomes after successful direct-acting antiviral therapy for patients with chronic hepatitis $\mathrm{C}$ and decompensated cirrhosis. J. Hepatol. 2016, 65, 741-747. [CrossRef]

18. Tahata, Y.; Hikita, H.; Mochida, S.; Kawada, N.; Enomoto, N.; Ido, A.; Yoshiji, H.; Miki, D.; Hiasa, Y.; Takikawa, Y.; et al. Sofosbuvir plus velpatasvir treatment for hepatitis $C$ virus in patients with decompensated cirrhosis: A Japanese real-world multicenter study. J. Gastroenterol. 2021, 56, 67-77. [CrossRef] [PubMed]

19. Chan, J.; Kim, J.J.; Barrett, B.K.; Hamadeh, A.; Feld, J.J.; Wong, W.W.L. Cost-Effectiveness analysis of sofosbuvir and velpatasvir in chronic hepatitis C patients with decompensated cirrhosis. J. Viral Hepat. 2021, 28, 260-267. [CrossRef]

20. Hutchinson, S.J.; Valerio, H.; McDonald, S.A.; Yeung, A.; Pollock, K.; Smith, S.; Barclay, S.; Dillon, J.F.; Fox, R.; Bramley, P.; et al. Population impact of direct-acting antiviral treatment on new presentations of hepatitis C-related decompensated cirrhosis: A national record-linkage study. Gut 2020, 69, 2223-2231. [CrossRef]

21. Debnath, P.; Chandnani, S.; Rathi, P.; Nair, S.; Junare, P.; Udgirkar, S.; Singh, A.; Contractor, Q. A new model to predict response to direct-acting antiviral therapy in decompensated cirrhotics due to hepatitis C virus. Clin. Exp. Hepatol. 2020, 6, $253-262$. [CrossRef]

22. Verna, E.C.; Morelli, G.; Terrault, N.A.; Lok, A.S.; Lim, J.K.; di Bisceglie, A.M.; Zeuzem, S.; Landis, C.S.; Kwo, P.; Hassan, M.; et al. DAA therapy and long-term hepatic function in advanced/decompensated cirrhosis: Real-world experience from HCV-TARGET cohort. J. Hepatol. 2020, 73, 540-548. [CrossRef]

23. Corouge, M.; Vallet-Pichard, A.; Pol, S. HCV and the kidney. Liver Int. 2016, 36, 28-33. [CrossRef] [PubMed]

24. Barsoum, R.S.; William, E.A.; Khalil, S.S. Hepatitis C and kidney disease: A narrative review. J. Adv. Res. 2017, 8, 113-130. [CrossRef]

25. Dai, C.-Y.; Chuang, W.-L.; Yu, M.-L. EASL recommendations on treatment of hepatitis C: Final update of the series-Some issues. J. Hepatol. 2021, 74, 473-474. [CrossRef] [PubMed]

26. Lai, T.-S.; Lee, M.-H.; Yang, H.-I.; You, S.-L.; Lu, S.-N.; Wang, L.-Y.; Yuan, Y.; L'Italien, G.; Chien, K.-L.; Chen, C.-J.; et al. Hepatitis $\mathrm{C}$ viral load, genotype, and increased risk of developing end-stage renal disease: REVEAL-HCV study. Hepatology 2017, 66, 784-793. [CrossRef] [PubMed]

27. Ohlendorf, V.; Maasoumy, B. Renal function in HCV therapy: Just another thing to ignore? Liver Int. 2020, 40, 1018-1020. [CrossRef] [PubMed]

28. El-Serag, H.B.; Christie, I.C.; Puenpatom, A.; Castillo, D.; Kanwal, F.; Kramer, J.R. The effects of sustained virological response to direct-acting anti-viral therapy on the risk of extrahepatic manifestations of hepatitis C infection. Aliment. Pharmacol. Ther. 2019, 49, 1442-1447. [CrossRef] [PubMed]

29. Fabrizi, F.; Cerutti, R.; Porata, G.; Messa, P.; Ridruejo, E. Direct-Acting Antiviral Agents for HCV-Associated Glomerular Disease and the Current Evidence. Pathogens 2019, 8, 176. [CrossRef]

30. Sise, M.E.; Bloom, A.K.; Wisocky, J.; Lin, M.V.; Gustafson, J.L.; Lundquist, A.L.; Steele, D.; Thiim, M.; Williams, W.W.; Hashemi, N.; et al. Treatment of hepatitis $\mathrm{C}$ virus-associated mixed cryoglobulinemia with direct-acting antiviral agents. Hepatology 2016, 63, 408-417. [CrossRef]

31. Gane, E.E.; Lawitz, E.; Pugatch, D.D.; Papatheodoridis, G.G.; Bräu, N.N.; Brown, A.A.; Pol, S.; Leroy, V.V.; Persico, M.M.; Moreno, C.; et al. Glecaprevir and Pibrentasvir in Patients with HCV and Severe Renal Impairment. N. Engl. J. Med. 2017, 377, 1448-1455. [CrossRef]

32. De Nicola, S.; Aghemo, A. The quest for safe and effective treatments of chronic hepatitis $C$ in patients with kidney impairment. Liver Int. 2016, 36, 791-793. [CrossRef]

33. Lawitz, E.; Landis, C.S.; Flamm, S.L.; Bonacini, M.; Ortiz-Lasanta, G.; Huang, J.; Zhang, J.; Kirby, B.J.; de-Oertel, S.; Hyland, R.H.; et al. Sofosbuvir plus ribavirin and sofosbuvir plus ledipasvir in patients with genotype 1 or 3 hepatitis $C$ virus and severe renal impairment: A multicentre, phase 2b, non-randomised, open-label study. Lancet Gastroenterol. Hepatol. 2020, 5 , 918-926. [CrossRef]

34. Borgia, S.M.; Dearden, J.; Yoshida, E.M.; Shafran, S.D.; Brown, A.; Ben-Ari, Z.; Cramp, M.E.; Cooper, C.; Foxton, M.; Rodriguez, C.F.; et al. Sofosbuvir/velpatasvir for 12 weeks in hepatitis $C$ virus-infected patients with end-stage renal disease undergoing dialysis. J. Hepatol. 2019, 71, 660-665. [CrossRef] [PubMed]

35. Cox-North, P.; Hawkins, K.L.; Rossiter, S.T.; Hawley, M.N.; Bhattacharya, R.; Landis, C.S. Sofosbuvir-based regimens for the treatment of chronic hepatitis C in severe renal dysfunction. Hepatol. Commun. 2017, 1, 248-255. [CrossRef] [PubMed]

36. Saxena, V.; Koraishy, F.M.; Sise, M.E.; Lim, J.K.; Schmidt, M.M.; Chung, R.T.; Liapakis, A.; Nelson, D.R.; Fried, M.W.; Terrault, N.A.; et al. Safety and efficacy of sofosbuvir-containing regimens in hepatitis C-infected patients with impaired renal function. Liver Int. 2016, 36, 807-816. [CrossRef] [PubMed]

37. Taneja, S.; Duseja, A.; Mehta, M.; De, A.; Verma, N.; Premkumar, M.; Dhiman, R.K.; Singh, V.; Singh, M.P.; Ratho, R.K.; et al. Sofosbuvir and Velpatasvir combination is safe and effective in treating chronic hepatitis $\mathrm{C}$ in end-Stage renal disease on maintenance haemodialysis. Liver Int. 2021, 41, 705-709. [CrossRef]

38. Solitano, V.; Aghemo, A. Sofosbuvir in HCV patients with chronic kidney disease: No time for caution. Liver Int. 2021, 41, 646-648. [CrossRef] 
39. Wang, C.; Ji, D.; Chen, J.; Shao, Q.; Li, B.; Liu, J.; Wu, V.; Wong, A.; Wang, Y.; Zhang, X.; et al. Hepatitis due to Reactivation of Hepatitis B Virus in Endemic Areas Among Patients with Hepatitis C Treated with Direct-acting Antiviral Agents. Clin. Gastroenterol. Hepatol. 2017, 15, 132-136. [CrossRef] [PubMed]

40. Liu, C.-J.; Chuang, W.-L.; Sheen, I.-S.; Wang, H.-Y.; Chen, C.-Y.; Tseng, K.-C.; Chang, T.-T.; Massetto, B.; Yang, J.C.; Yun, C.; et al. Efficacy of Ledipasvir and Sofosbuvir Treatment of HCV Infection in Patients Coinfected with HBV. Gastroenterology 2018, 154, 989-997. [CrossRef] [PubMed]

41. Chen, G.; Wang, C.; Chen, J.; Ji, D.; Wang, Y.; Wu, V.; Karlberg, J.; Lau, G.; Karlberg, J. Hepatitis B reactivation in hepatitis B and C coinfected patients treated with antiviral agents: A systematic review and meta-analysis. Hepatology 2017, 66, 13-26. [CrossRef]

42. Mücke, M.M.; Backus, L.I.; Mücke, V.T.; Coppola, N.; Preda, C.M.; Yeh, M.-L.; Tang, L.S.Y.; Belperio, P.S.; Wilson, E.M.; $\mathrm{Yu}$, M.-L.; et al. Hepatitis B virus reactivation during direct-acting antiviral therapy for hepatitis C: A systematic review and meta-analysis. Lancet Gastroenterol. Hepatol. 2018, 3, 172-180. [CrossRef]

43. El Kassas, M.; Shimakawa, Y.; Ali-Eldin, Z.; Funk, A.-L.; Wifi, M.N.; Zaky, S.; El-Raey, F.; Esmat, G.; Fontanet, A. Risk of hepatitis $B$ virus reactivation with direct-acting antivirals against hepatitis $C$ virus: A cohort study from Egypt and meta-analysis of published data. Liver Int. 2018, 38, 2159-2169. [CrossRef] [PubMed]

44. Calvaruso, V.; Ferraro, D.; Licata, A.; Bavetta, M.G.; Petta, S.; Bronte, F.; Colomba, G.; Craxì, A.; di Marco, V. HBV reactivation in patients with HCV/HBV cirrhosis on treatment with direct-acting antivirals. J. Viral Hepat. 2018, 25, 72-79. [CrossRef] [PubMed]

45. Belperio, P.S.; Shahoumian, T.A.; Mole, L.A.; Backus, L.I. Evaluation of hepatitis B reactivation among 62,920 veterans treated with oral hepatitis C antivirals. Hepatology 2017, 66, 27-36. [CrossRef] [PubMed]

46. Yeh, M.-L.; Huang, C.-F.; Huang, C.-I.; Holmes, J.A.; Hsieh, M.-H.; Tsai, Y.-S.; Liang, P.-C.; Tsai, P.-C.; Hsieh, M.-Y.; Lin, Z.-Y.; et al. Hepatitis B-related outcomes following direct-acting antiviral therapy in Taiwanese patients with chronic HBV/HCV co-infection. J. Hepatol. 2020, 73, 62-71. [CrossRef]

47. Terrault, N.A.; Lok, A.S.F.; McMahon, B.J.; Chang, K.-M.; Hwang, J.P.; Jonas, M.M.; Brown, R.S.; Bzowej, N.H.; Wong, J.B. Update on prevention, diagnosis, and treatment of chronic hepatitis B: AASLD 2018 hepatitis B guidance. Hepatology 2018, 67, 1560-1599. [CrossRef]

48. Benhamou, Y.; Bochet, M.; di Martino, V.; Charlotte, F.; Azria, F.; Coutellier, A.; Vidaud, M.; Opolon, P.; Katlama, C.; Poynard, T.; et al. Liver fibrosis progression in human immunodeficiency virus and hepatitis $\mathrm{C}$ virus coinfected patients. Hepatology 1999, 30, 1054-1058. [CrossRef]

49. Abutaleb, A.; Sherman, K.E. A changing paradigm: Management and treatment of the HCV/HIV-co-infected patient. Hepatol. Int. 2018, 12, 500-509. [CrossRef]

50. Garrison, K.L.; German, P.; Mogalian, E.; Mathias, A. The Drug-Drug Interaction Potential of Antiviral Agents for the Treatment of Chronic Hepatitis C Infection. Drug Metab. Dispos. 2018, 46, 1212-1225. [CrossRef]

51. Regazzi, M.; Maserati, R.; Villani, P.; Cusato, M.; Zucchi, P.; Briganti, E.; Roda, R.; Sacchelli, L.; Gatti, F.; Foglie, P.D.; et al. Clinical Pharmacokinetics of Nelfinavir and Its Metabolite M8 in Human Immunodeficiency Virus (HIV)-Positive and HIV-Hepatitis C Virus-Coinfected Subjects. Antimicrob. Agents Chemother. 2005, 49, 643-649. [CrossRef]

52. Sulkowski, M.S.; Naggie, S.; Lalezari, J.; Fessel, W.J.; Mounzer, K.; Shuhart, M.; Luetkemeyer, A.F.; Asmuth, D.; Gaggar, A.; Ni, L.; et al. Sofosbuvir and Ribavirin for Hepatitis C in Patients with HIV Coinfection. JAMA 2014, 312, 353-361. [CrossRef]

53. Molina, J.-M.; Orkin, C.; Iser, D.M.; Zamora, F.-X.; Nelson, M.; Stephan, C.; Massetto, B.; Gaggar, A.; Ni, L.; Svarovskaia, E.; et al. Sofosbuvir plus ribavirin for treatment of hepatitis $C$ virus in patients co-infected with HIV (PHOTON-2): A multicentre, open-label, non-randomised, phase 3 study. Lancet 2015, 385, 1098-1106. [CrossRef]

54. Rockstroh, J.K.; Lacombe, K.; Viani, R.M.; Orkin, C.; Wyles, D.; Luetkemeyer, A.F.; Soto-Malave, R.; Flisiak, R.; Bhagani, S.; Sherman, K.E.; et al. Efficacy and Safety of Glecaprevir/Pibrentasvir in Patients Coinfected With Hepatitis C Virus and Human Immunodeficiency Virus Type 1: The Expedition-2 Study. Clin. Infect. Dis. 2018, 67, 1010-1017. [CrossRef]

55. Zeuzem, S.; Foster, G.R.; Wang, S.; Asatryan, A.; Gane, E.; Feld, J.J.; Asselah, T.; Bourlière, M.; Ruane, P.J.; Wedemeyer, H.; et al. Glecaprevir-Pibrentasvir for 8 or 12 Weeks in HCV Genotype 1 or 3 Infection. N. Engl. J. Med. 2018, 378, 354-369. [CrossRef] [PubMed]

56. Osinusi, A.; Townsend, K.; Kohli, A.; Nelson, A.; Seamon, C.; Meissner, E.G.; Bon, D.; Silk, R.; Gross, C.; Price, A.; et al. Virologic Response Following Combined Ledipasvir and Sofosbuvir Administration in Patients With HCV Genotype 1 and HIV Co-infection. JAMA 2015, 313, 1232-1239. [CrossRef] [PubMed]

57. Naggie, S.; Cooper, C.; Saag, M.; Workowski, K.; Ruane, P.; Towner, W.J.; Marks, K.; Luetkemeyer, A.; Baden, R.P.; Sax, P.E.; et al. Ledipasvir and Sofosbuvir for HCV in Patients Coinfected with HIV-1. N. Engl. J. Med. 2015, 373, 705-713. [CrossRef]

58. Sulkowski, M.; Hezode, C.; Gerstoft, J.; Vierling, J.M.; Mallolas, J.; Pol, S.; Kugelmas, M.; Murillo, A.; Weis, N.; Nahass, R.; et al. Efficacy and safety of 8 weeks versus 12 weeks of treatment with grazoprevir (MK-5172) and elbasvir (MK-8742) with or without ribavirin in patients with hepatitis $\mathrm{C}$ virus genotype 1 mono-infection and HIV/hepatitis $\mathrm{C}$ virus co-infection (C-WORTHY): $\mathrm{A}$ randomised, open-label phase 2 trial. Lancet 2015, 385, 1087-1097. [CrossRef] [PubMed]

59. Rockstroh, J.K.; Nelson, M.; Katlama, C.; Lalezari, J.; Mallolas, J.; Bloch, M.; Matthews, G.V.; Saag, M.S.; Zamor, P.J.; Orkin, C.; et al. Efficacy and safety of grazoprevir (MK-5172) and elbasvir (MK-8742) in patients with hepatitis C virus and HIV co-infection (C-EDGE CO-INFECTION): A non-randomised, open-label trial. Lancet HIV 2015, 2, e319-e327. [CrossRef] 
60. Wyles, D.L.; Ruane, P.J.; Sulkowski, M.S.; Dieterich, D.; Luetkemeyer, A.; Morgan, T.R.; Sherman, K.E.; Dretler, R.; Fishbein, D.; Gathe, J.C.; et al. Daclatasvir plus Sofosbuvir for HCV in Patients Coinfected with HIV-1. N. Engl. J. Med. 2015, 373, 714-725. [CrossRef]

61. Sulkowski, M.S.; Eron, O.J.; Wyles, D.; Trinh, R.; Lalezari, J.; Wang, C.; Slim, J.; Bhatti, L.; Gathe, J.; Ruane, P.J.; et al. Ombitasvir, Paritaprevir Co-dosed With Ritonavir, Dasabuvir, and Ribavirin for Hepatitis C in Patients Co-infected with HIV-1: A Randomized Trial. JAMA 2015, 313, 1223-1231. [CrossRef]

62. Wyles, D.; Saag, M.; Lalezari, J.; Adeyemi, O.; Bhatti, L.; Khatri, A.; King, J.R.; Trinh, R.; Ruane, P.; Viani, R.M.; et al. TURQUOISE-I Part 1b: Ombitasvir/Paritaprevir/Ritonavir and Dasabuvir with Ribavirin for Hepatitis C Virus Infection in HIV-1 Coinfected Patients on Darunavir. J. Infect. Dis. 2017, 215, 599-605. [CrossRef]

63. Wyles, D.; Bräu, N.; Kottilil, S.; Daar, E.S.; Ruane, P.; Workowski, K.; Luetkemeyer, A.; Adeyemi, O.; Kim, A.Y.; Doehle, B.; et al. Sofosbuvir and Velpatasvir for the Treatment of Hepatitis C Virus in Patients Coinfected With Human Immunodeficiency Virus Type 1: An Open-Label, Phase 3 Study. Clin. Infect. Dis. 2017, 65, 6-12. [CrossRef]

64. Chung, R.T.; Davis, G.L.; Jensen, D.M.; Masur, H.; Saag, M.S.; Thomas, D.L.; Aronsohn, A.I.; Charlton, M.R.; Feld, J.J.; Fontana, R.J.; et al. Hepatitis C guidance: AASLD-IDSA recommendations for testing, managing, and treating adults infected with hepatitis C virus. Hepatology 2015, 62, 932-954. [CrossRef]

65. Ryom, L.; Cotter, A.; de Miguel, R.; Béguelin, C.; Podlekareva, D.; Arribas, J.R.; Marzolini, C.; Mallon, P.G.M.; Rauch, A.; Kirk, O.; et al. 2019 update of the European AIDS Clinical Society Guidelines for treatment of people living with HIV version 10.0. HIV Med. 2020, 21, 617-624. [CrossRef]

66. Schlabe, S.; Rockstroh, J.K. Advances in the treatment of HIV/HCV coinfection in adults. Expert Opin. Pharmacother. 2018, 19, 49-64. [CrossRef]

67. Sikavi, C.; Chen, P.H.; Lee, A.D.; Saab, E.G.; Choi, G.; Saab, S. Hepatitis C and human immunodeficiency virus coinfection in the era of direct-acting antiviral agents: No longer a difficult-to-treat population. Hepatology 2018, 67, 847-857. [CrossRef]

68. Razavi, H.; Gonzalez, Y.S.; Yuen, C.; Cornberg, M. Global timing of hepatitis C virus elimination in high-income countries. Liver Int. 2020, 40, 522-529. [CrossRef] [PubMed]

69. Popping, S.; Bade, D.; Boucher, C.; van der Valk, M.; El-Sayed, M.; Sigurour, O.; Sypsa, V.; Morgan, T.; Gamkrelidze, A.; Mukabatsinda, C.; et al. The global campaign to eliminate HBV and HCV infection: International Viral Hepatitis Elimination Meeting and core indicators for development towards the 2030 elimination goals. J. Virus Erad. 2019, 5, 60-66. [CrossRef]

70. Filipe, A.D.S.; Sreenu, V.; Hughes, J.; Aranday-Cortes, E.; Irving, W.L.; Foster, G.R.; Agarwal, K.; Rosenberg, W.; Macdonald, D.; Richardson, P.; et al. Response to DAA therapy in the NHS England Early Access Programme for rare HCV subtypes from low and middle income countries. J. Hepatol. 2017, 67, 1348-1350. [CrossRef] [PubMed]

71. Childs, K.; Davis, C.; Cannon, M.; Montague, S.; Filipe, A.; Tong, L.; Simmonds, P.; Smith, D.; Thomson, E.C.; Dusheiko, G.; et al. Suboptimal SVR rates in African patients with atypical genotype 1 subtypes: Implications for global elimination of hepatitis C. J. Hepatol. 2019, 71, 1099-1105. [CrossRef] [PubMed]

72. Wasitthankasem, R.; Vongpunsawad, S.; Siripon, N.; Suya, C.; Chulothok, P.; Chaiear, K.; Rujirojindakul, P.; Kanjana, S.; Theamboonlers, A.; Tangkijvanich, P.; et al. Genotypic Distribution of Hepatitis C Virus in Thailand and Southeast Asia. PLoS ONE 2015, 10, e0126764. [CrossRef]

73. Pawlotsky, J.M. DAA failures in African patients with "unusual” HCV subtypes: Hey! Didn't you know there was another world? J. Hepatol. 2019, 71, 1070-1072. [CrossRef] [PubMed]

74. Gupta, N.; Mbituyumuremyi, A.; Kabahizi, J.; Ntaganda, F.; Muvunyi, C.M.; Shumbusho, F.; Musabeyezu, E.; Mukabatsinda, C.; Ntirenganya, C.; van Nuil, J.I.; et al. Treatment of chronic hepatitis C virus infection in Rwanda with ledipasvir-sofosbuvir (SHARED): A single-arm trial. Lancet Gastroenterol. Hepatol. 2019, 4, 119-126. [CrossRef]

75. Bertoli, A.; Sorbo, M.C.; Aragri, M.; Lenci, I.; Teti, E.; Polilli, E.; di Maio, V.C.; Gianserra, L.; Biliotti, E.; Masetti, C.; et al. Prevalence of Single and Multiple Natural NS3, NS5A and NS5B Resistance-Associated Substitutions in Hepatitis C Virus Genotypes 1-4 in Italy. Sci. Rep. 2018, 8, 8988. [CrossRef]

76. Fourati, S.; Rodriguez, C.; Hézode, C.; Soulier, A.; Ruiz, I.; Poiteau, L.; Chevaliez, S.; Pawlotsky, J.M. Frequent Antiviral Treatment Failures in Patients Infected with Hepatitis C Virus Genotype 4, Subtype 4r. Hepatology 2019, 69, 513-523. [CrossRef] [PubMed]

77. Zeuzem, S.; Dvory-Sobol, H.; Brainard, D.M. Reply to: "Response to DAA therapy in the NHS England Early Access Programme for rare HCV subtypes from low and middle income countries". J. Hepatol. 2017, 67, 1350-1352. [CrossRef]

78. Spearman, C.W.; Dusheiko, G.M.; Hellard, M.; Sonderup, M. Hepatitis C. Lancet 2019, 394, 1451-1466. [CrossRef]

79. Kondili, L.A.; Gaeta, G.B.; Brunetto, M.R.; di Leo, A.; Iannone, A.; Santantonio, T.A.; Giammario, A.; Raimondo, G.; Filomia, R.; Coppola, C.; et al. Incidence of DAA failure and the clinical impact of retreatment in real-life patients treated in the advanced stage of liver disease: Interim evaluations from the PITER network. PLoS ONE 2017, 12, e0185728. [CrossRef] [PubMed]

80. Yen, Y.-H.; Chen, C.-H.; Hung, C.-H.; Wang, J.-H.; Lu, S.-N.; Kee, K.-M.; Hu, T.-H. Active hepatocellular carcinoma is an independent risk factor of direct-acting antiviral treatment failure: A retrospective study with prospectively collected data. PLoS ONE 2019, 14, e0222605. [CrossRef] [PubMed]

81. Degasperi, E.; Spinetti, A.; Lombardi, A.; Landonio, S.; Rossi, M.C.; Pasulo, L.; Pozzoni, P.; Giorgini, A.; Fabris, P.; Romano, A.; et al. Real-life effectiveness and safety of sofosbuvir/velpatasvir/voxilaprevir in hepatitis $C$ patients with previous DAA failure. J. Hepatol. 2019, 71, 1106-1115. [CrossRef] 
82. Zeuzem, S.; Mizokami, M.; Pianko, S.; Mangia, A.; Han, K.-H.; Martin, R.; Svarovskaia, E.; Dvory-Sobol, H.; Doehle, B.; Hedskog, C.; et al. NS5A resistance-associated substitutions in patients with genotype 1 hepatitis $C$ virus: Prevalence and effect on treatment outcome. J. Hepatol. 2017, 66, 910-918. [CrossRef]

83. Jeong, Y.; Jin, B.; Lee, H.W.; Park, H.J.; Park, J.Y.; Kim, D.Y.; Han, K.-H.; Ahn, S.H.; Kim, S. Evolution and persistence of resistance-associated substitutions of hepatitis $C$ virus after direct-acting antiviral treatment failures. J. Viral Hepat. 2018, 25, 1251-1259. [CrossRef] [PubMed]

84. Ghany, M.G.; Morgan, T.R.; Panel, A.H.C.G.; Marks, K.M.; Wyles, D.L.; Aronsohn, A.I.; Bhattacharya, D.; Broder, T.; FaladeNwulia, O.O.; Feld, J.J.; et al. Hepatitis C Guidance 2019 Update: American Association for the Study of Liver Diseases-Infectious Diseases Society of America Recommendations for Testing, Managing, and Treating Hepatitis C Virus Infection. Hepatology 2020, 71, 686-721. [CrossRef] [PubMed]

85. Bourlière, M.; Gordon, S.C.; Flamm, S.L.; Cooper, C.L.; Ramji, A.; Tong, M.; Ravendhran, N.; Vierling, J.M.; Tran, T.T.; Pianko, S.; et al. Sofosbuvir, Velpatasvir, and Voxilaprevir for Previously Treated HCV Infection. N. Engl. J. Med. 2017, 376, 2134-2146. [CrossRef] [PubMed]

86. Belperio, P.S.; Shahoumian, T.A.; Loomis, T.P.; Backus, L.I. Real-world effectiveness of sofosbuvir/velpatasvir/voxilaprevir in 573 direct-acting antiviral experienced hepatitis C patients. J. Viral Hepat. 2019, 26, 980-990. [CrossRef]

87. Da, B.L.; Lourdusamy, V.; Kushner, T.; Dieterich, D.; Saberi, B. Efficacy of sofosbuvir/velpatasvir/voxilaprevir in direct-acting antiviral experienced patients with hepatitis C virus. Eur. J. Gastroenterol. Hepatol. 2020, 33, 859-861. [CrossRef]

88. Wyles, D.; Weiland, O.; Yao, B.; Weilert, F.; Dufour, J.-F.; Gordon, S.C.; Stoehr, A.; Brown, A.; Mauss, S.; Zhang, Z.; et al. Retreatment of patients who failed glecaprevir/pibrentasvir treatment for hepatitis C virus infection. J. Hepatol. 2019, 70, 1019-1023. [CrossRef]

89. Gane, E.J.; Shiffman, M.L.; Etzkorn, K.; Morelli, G.; Stedman, C.A.M.; Davis, M.N.; Hinestrosa, F.; Dvory-Sobol, H.; Huang, K.C.; Osinusi, A.; et al. Sofosbuvir-velpatasvir with ribavirin for 24 weeks in hepatitis $C$ virus patients previously treated with a direct-acting antiviral regimen. Hepatology 2017, 66, 1083-1089. [CrossRef]

90. Krassenburg, L.A.P.; Maan, R.; Ramji, A.; Manns, M.P.; Cornberg, M.; Wedemeyer, H.; de Knegt, R.J.; Hansen, B.E.; Janssen, H.L.A.; de Man, R.A.; et al. Clinical outcomes following DAA therapy in patients with HCV-related cirrhosis depend on disease severity. J. Hepatol. 2020. [CrossRef] 